\title{
Perancangan Aplikasi Estimasi Harga Pokok Penjualan dan Produksi Berbasis Web
}

\author{
Nova Andriani ${ }^{1}$,Jenie Sundari ${ }^{2}$ \\ ${ }^{12}$ Fakultas Teknologi Informasi, Universitas Nusa Mandiri \\ 12170159@nusamandiri.ac.id, ${ }^{2}$ jenie.jni@nusamandiri.ac.id
}

Coprespondent Author :jenie.jni@nusamandiri.ac.id

\begin{abstract}
The speed of data transformation is very much needed in order to increase work and information needs. this is very much needed in all fields. especially in the industrial sector. we can use this growing technology for many things, to minimize errors and also make work easier. it is a pity if we can take advantage of existing technology but calculations and work are still done manually. therefore, in research this is designed a web-based application using php and mysql. with this application design, it is expected to be able to make work more effective and efficient. and in this sophisticated digital age, it would be better if we choose to reduce the use of paper. this can also save operational costs and a step to reduce global warming. and during a pandemic like this, it is very necessary to reduce face-to-face interactions. to reduce that interaction and make it easier to store data and search for data in making reports and calculating cost estimates,make it application design of web- based cost of goods sold and production estimation application.
\end{abstract}

KEYWORD - : PHP, MYSQL, Application Design,

Cost of Goods, Web.

Abstrak - kecepatan transformasi data sangat dibutuhkan dalam rangka peningkatan kebutuhan pekerjaan dan informasi. ini sangat dibutuhkan di segala bidang. terutama di sektor industri. kita dapat menggunakan teknologi yang berkembang ini untuk banyak hal, untuk meminimalkan kesalahan dan juga mempermudah pekerjaan. sangat disayangkan jika kita dapat memanfaatkan teknologi yang ada namun perhitungan dan pekerjaan masih dilakukan secara manual. oleh karena itu, pada penelitian ini dirancang sebuah aplikasi berbasis web dengan menggunakan php dan mysql. dengan adanya perancangan aplikasi ini diharapkan dapat membuat pekerjaan menjadi lebih efektif dan efisien. dan di era digital yang serba canggih ini, alangkah baiknya jika kita memilih untuk mengurangi penggunaan kertas. hal ini juga dapat menghemat biaya operasional dan langkah untuk mengurangi pemanasan global. dan di masa pandemi seperti ini, sangat perlu untuk mengurangi interaksi tatap muka. untuk mengurangi interaksi tersebut dan mempermudah penyimpanan data dan pencarian data dalam pembuatan laporan dan perhitungan perkiraan biaya, maka dibuatlah perancangan aplikasi aplikasi estimasi harga pokok penjualan dan produksi berbasis web.

Kata kunci - PHP, MYSQL, desai aplikasi, harga pokok, web

\section{PENDAHULUAN}

Di Zaman Teknologi yang makin berkembang dan canggih ini Teknologi sangat di butuhkan di berbagai bidang demi meminimalisir kesalahan dan menunjang efisiensi dan keefektifan pekerjaan.Contohnya di bidang Perindustrian, Perkantoran, Pemerintahan, Pendidikan, Perekonomian, hampir segala aspek memanfaatkan teknologi yang ada. Kecepatan transformasi data sangat di perlukan demi meningkatkan pekerjaan dan kebutuhan informasi. Sangat di sayangkanapabila kita bisa memanfaatkan teknologi yang ada namun perhitungan dan pekerjaan masih di lakukan secara manual. Contohnya pada penelitian di PT Sinar Pelangi Kemasindo untuk perhitungan harga pokok penjualan dan produksi masih menggunakan Microsoft Excell, Penyimpanan data masih menggunakan flash disk yang rentan rusak dan hilang.

Serta di masa pandemi seperti ini sangat di perlukan mengurangi interaksi tatap muka.Apabila menggunakan banyak kertas untuk mengeprint lembar laporan dan saling bertatap muka maka di takutkan akan sangat rentan terpapar. Untuk mengurangi interaksi itu dan memudahkan juga dalam penyimpanan data serta pencarian data maka tercetuslah ide untuk membuat "Perancangan Aplikasi Estimasi Perhitungan Harga Pokok Penjualan dan Produksi Berbasis Web".

\section{METODE PENELITIAN}

a. Observasi

Observasi yaitu mengamati suatu benda atau objek. Pengamatan pada penelitian ini di lakukan secara langsung karena penulis langsung terjun kelapangan mengamati objek yang ada di dalam lokasi kegiatan penelitian.

b. Wawancara

Wawancara yang di lakukan pada PT.Sinar pelangi Kemasindo ini di lakukan secara langsung pada lokasi kegiatan dengan narasumber terkait yang berkontribusi dalam kegiatan penelitian. 


\section{c. Studi Pustaka}

Teknik pengumpulan data ini menggunakan tinjauan pustaka pada buku-buku, bahanbahan tertulis serta referensi- referensi yang relevan dan terjun langsung pada studi kasus dengan penelitian yang sedang dilakukan.

\section{LANDASAN TEORI}

Harga Pokok sangat penting dalam proses produksi dan penjualan. Maka setiap perusahaan bidang Manufaktur sangat membutuhkan perhitungan harga pokok penjualan ataupun produksi.Dengan adanya perhitungan estimasi harga penjualan maka dapat membuat perusahaan dapat menetapkan harga jual ke pelanggan.Harga pokok penjualan merupakan besar biaya yang di tentukan untuk menghasilkan harga barang jadi melalui perhitungan strategi penjualan oleh perushaan.Harga pokok penjualan menjadi penentu untuk mengambil keputusan berapa harga jual yang akan di tetapkan kepada pelanggan.

Sedangkan Harga Pokok Produksi yaitu besar Biaya yang di perlukan untuk menghitung proses produksi barang jadi.Merupakan Biaya langsung maupun biaya tidak langsung. Harga pokok produksi ini menjadi penentu besarnya biaya yang perlu di keluarkan dan berapa besarnya hasil laba/rugi yang di dapat dari penjualan barang setelah produksi barang selesai.

\section{A. Pemrograman Web}

Pemrograman web dapat di artikan sebagai proses pembuatan aplikasi atau program berbasis web dengan menggunakan bahasa pemrograman tertentu yang dapat memberikan intruksi kepada komputer sehingga dapat memproses data, menampilkan data danmenghasilkan informasi sesuai dengan keinginan.[1]

\section{B. Database}

Database adalah kumpulan dari data/field yang saling terkait yang dapat dimanipulasi dan disimpan. Setiap database akan memiliki indeks, tabel, dan sejumlah objek.[2]

\section{E.MYSQL}

MYSQL didirikan oleh perusahaan perangkat lunak di Swedia. Proyek itu di namai MYSQL, pertama kali di rilis untuk masyarakat umum pada akhir tahun 1996. MYSQL menempatkan penekanan khusus pada kecepatan dan skalabilitas, Sehingga menarik minat para pengembang di seluruh dunia dalam membangun situs web berkinerja. MYSQL adalah server database relasional yang menawarkan fitur yang sama yang di temukan dalam kompetitor lain. MYSQL juga menawarkan banyak mekanisme untuk mengelola data yang di kenal sebagai mesin penyimpanan. [3]

\section{F.UML (Unified Modelling language)}

uml merupakan sebuah bahasa pemodelan bestandar untuk memvisualisasikan atau menggambarkan desain Sistem. [4]

\section{G. ERD ( Entity Relation Diagram )}

Pemodelan ER merupakan pendekatan top down dalam perancangan basis data yang dimulai dengan mengidentifikasi data penting yang disebut entitas dan hubungan atau relationship antara entitas yang harus diwakili dalam model. Model ER biasanya adalah hasil analisis sistematis untuk mendefinisikan dan menggambarkan apa yang penting bagi sebuah proses bisnis. Model ER tidak mendefinisikan proses bisnis namun sekedar menyajikan skema data bisnis dalam bentuk grafis.(Budiarto, 2020)

\section{H. Use Case}

Use Case mendiskripsikan bagaimana pengguna dapat mencapai tujuan mereka dengan menggunakan sistem atau program aplikasi yang di buat. Use case biasanay mendifinisikan interaksi anatara aktor dan sistem, untuk mencapai suatu tujuan.(Budiarto, 2020)

\section{HASIL DAN PEMBAHASAN}

Beberapa software pendukung yang di butuhkan dalam membangun rancangan aplikasi harga pokok penjualan dan produksi yaitu :

1. Notepad

2. Balsamiq Mockup

3. Enterphrise Architecture

4. Xampp

5. Browser Firefox

\section{Tahap Analisis}

Perancangan aplikasi harga pokok penjualan dan produksi berbassis web ini dilakukan secara online. Dimana Marketing dan admin tidak perlu melakukan laporan secara tatap muka. Semua data dapat di input pada komputer masing-masing namun bisa saling terhubung.

A. Halaman Login

1. User (Marketing, Admin, Pimpinan) dapat melakukan login dengan memasukkan username dan password. 
B. Halaman Marketing
1. Marketing dapat mengelola data komposisi.
2. Marketing dapat mengelola data hpp penjualan.
3. Marketing dapat melaporkan data hpp penjualan.
4. Marketing dapat melihat data hpp penjualan.

5. Marketing dapat logout

C. Halaman Admin
1. Admin dapat mengelola data hpp produksi.

2. Admin dapat melaporkan data hpp produksi.

3. Admin dapat melihat data hpp produksi.

4. Admin dapat logout

D. Halaman Pimpinan

1. Pimpinan dapat melihat laporan hpp penjualan

2. Pimpinan dapat melihat laporan hpp produksi

3. Pimpinan dapat memberikan approve

4. Pimpinan dapat mengelola user.

5. Pimpinan dapat logout

\section{Use case}

Use case diagram menyajikan interaksi antara user dengan sistem. Berikut tampilan use case :

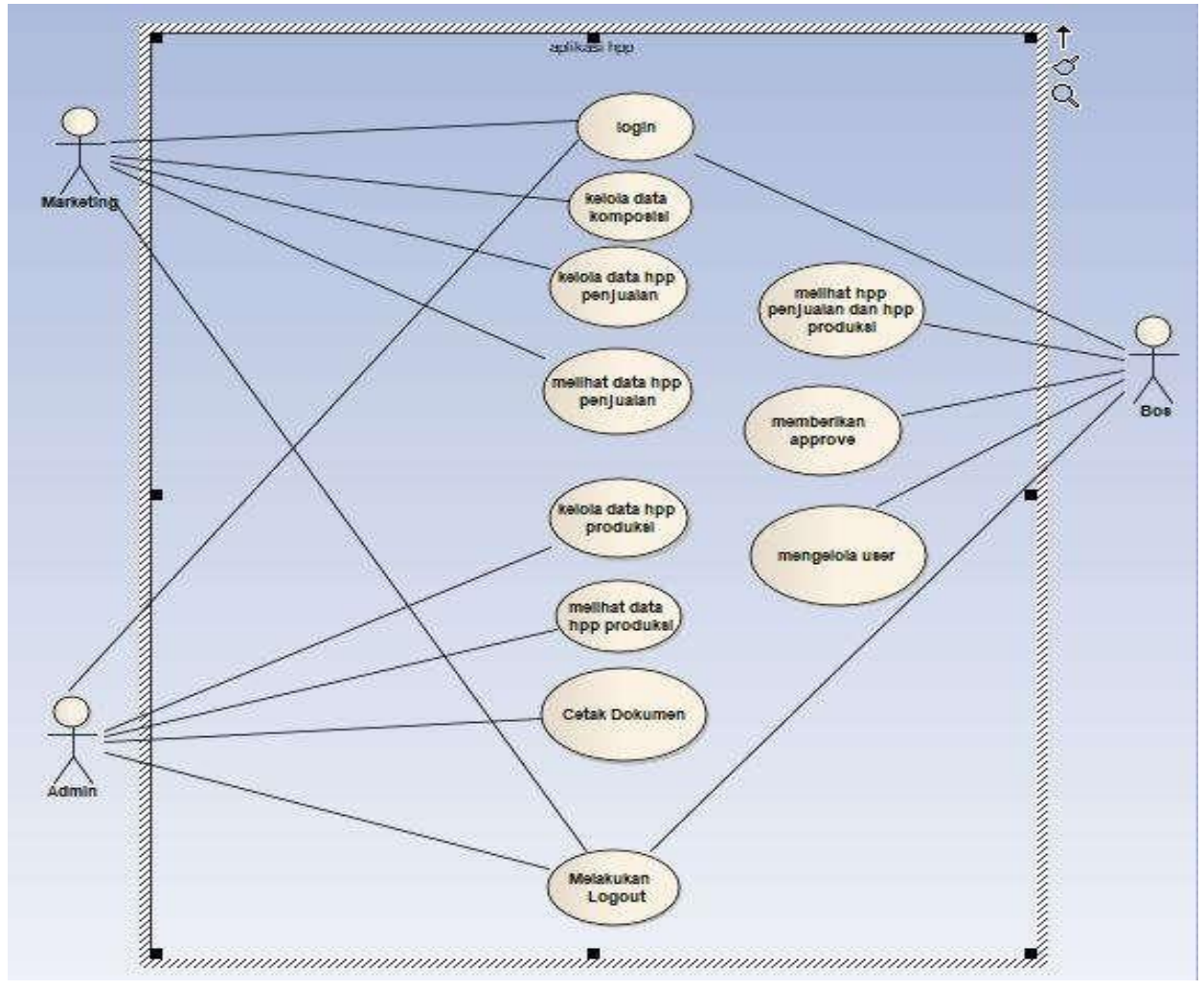

Gambar 4.1 Tampilan Use case 


\section{Desain}

Dalam desain untuk membangun Perancangan Aplikasi Harga Pokok Penjualan dan Produksi ini penulis akan membahas tentang kebutuhan system dalam pengembangan aplikasi.Kebutuhan sistem tersebut seperti desain database, software architecture, dan user interface. Desain database ini menghubungkan antara tabel dengan relasi atar tabel. Dalam penggambarannya adalah sebagai berikut

\section{Entity Relationship Diagram (ERD)}

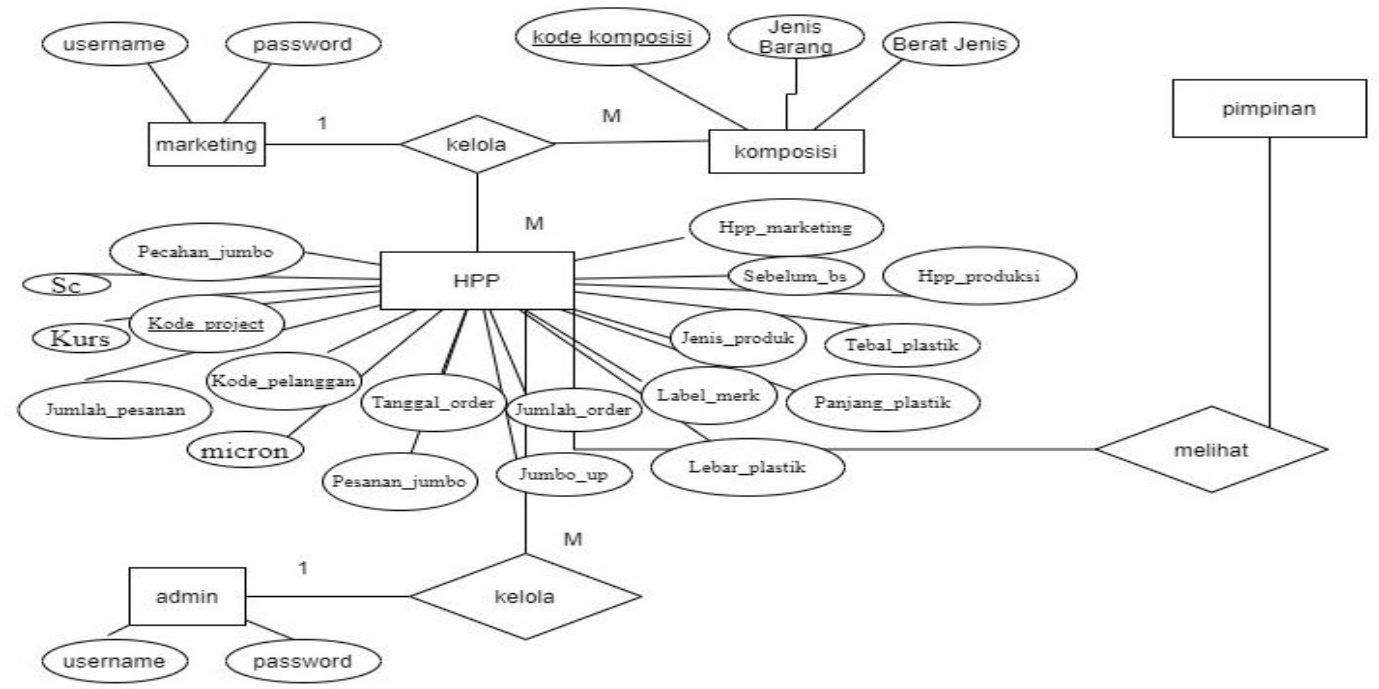

Gambar 4.2 Rancangan ERD

\section{Logical Record Structure (LRS)}

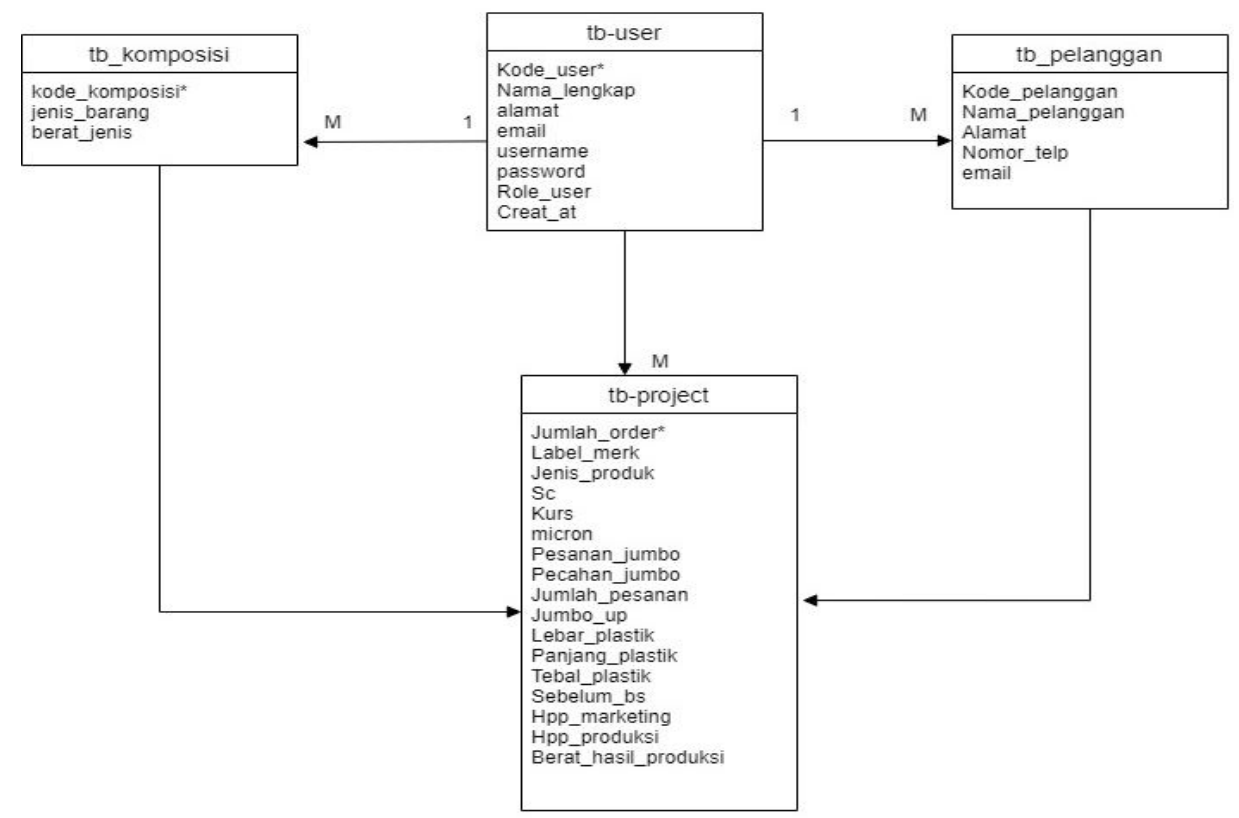

Gambar 4.3 LRS

\section{User Interface}

User interface merupakan tampilan visual sebagai penghubung antara user/pengguna dengan sistem aplikasi sehingga komputer dapat di gunakan. Berikut merupakan tampilan dari user interface : 


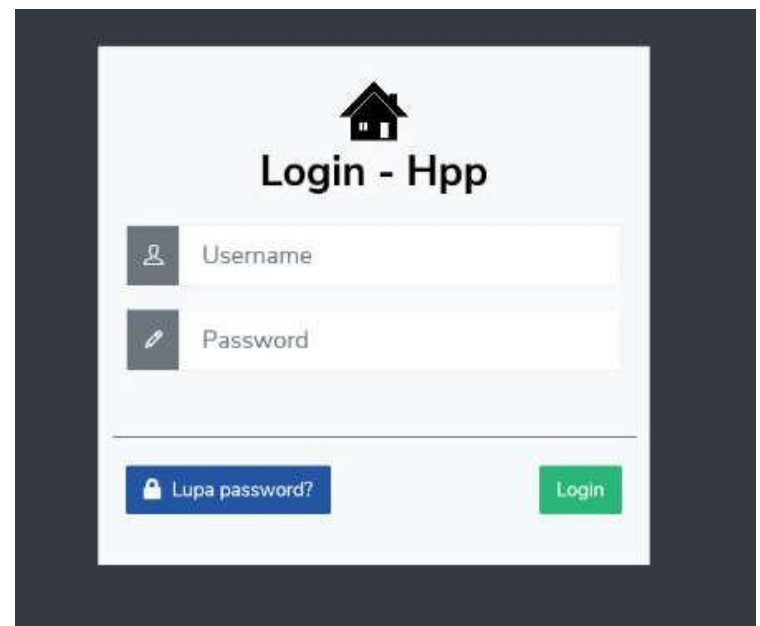

Gambar 4.4Halaman Login

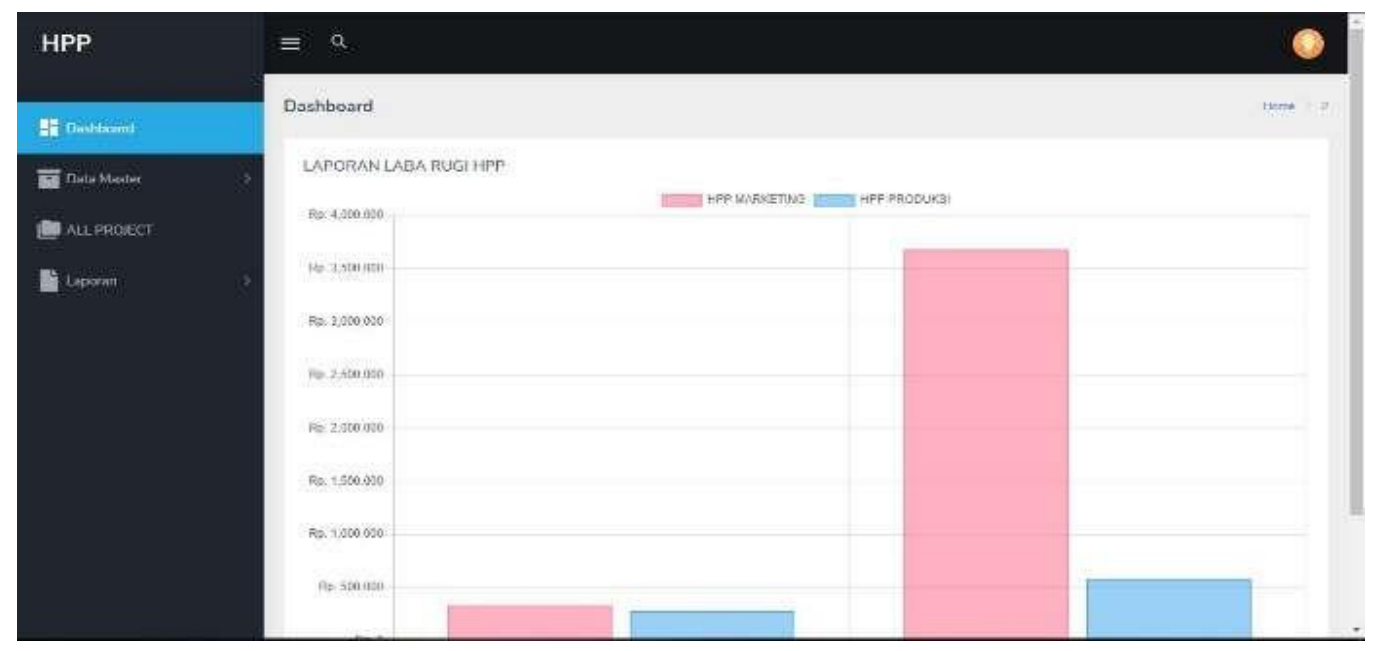

Gambar 4.5 Halaman Utama

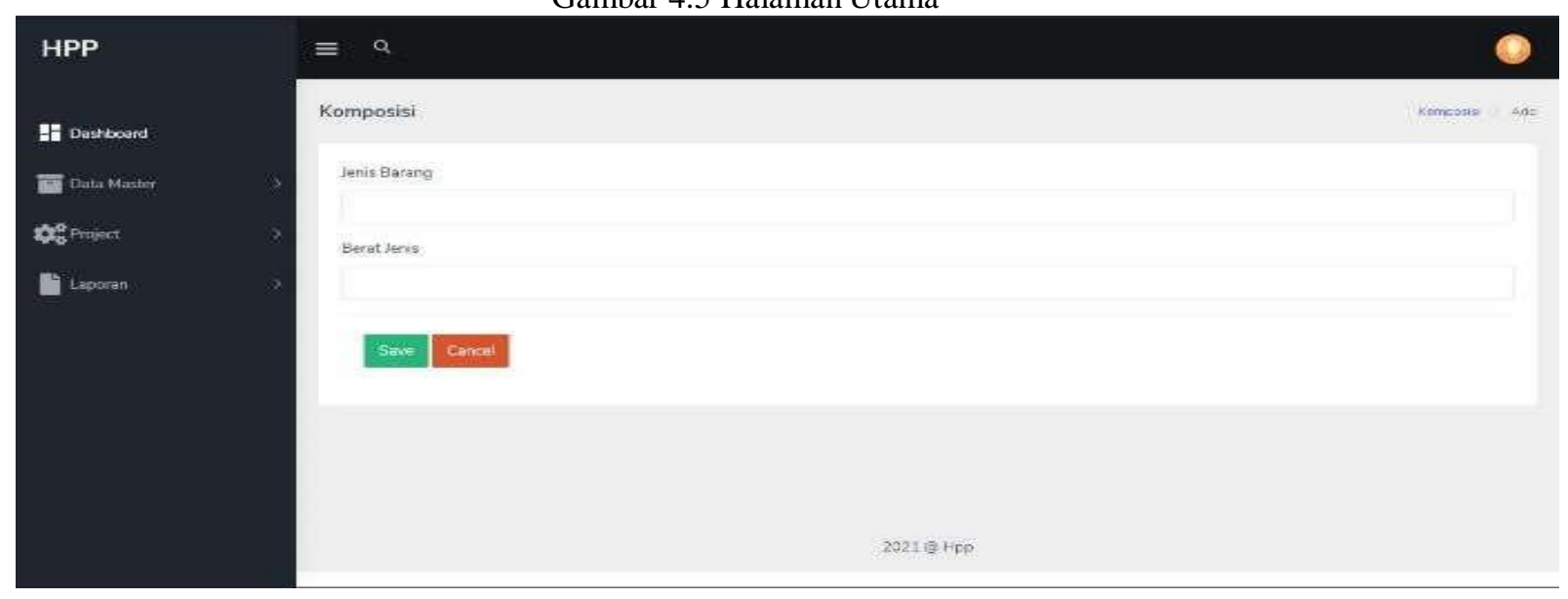

Gambar 4.6 Halaman Input Komposisi 




Gambar 4.7.Halaman Input Pelanggan

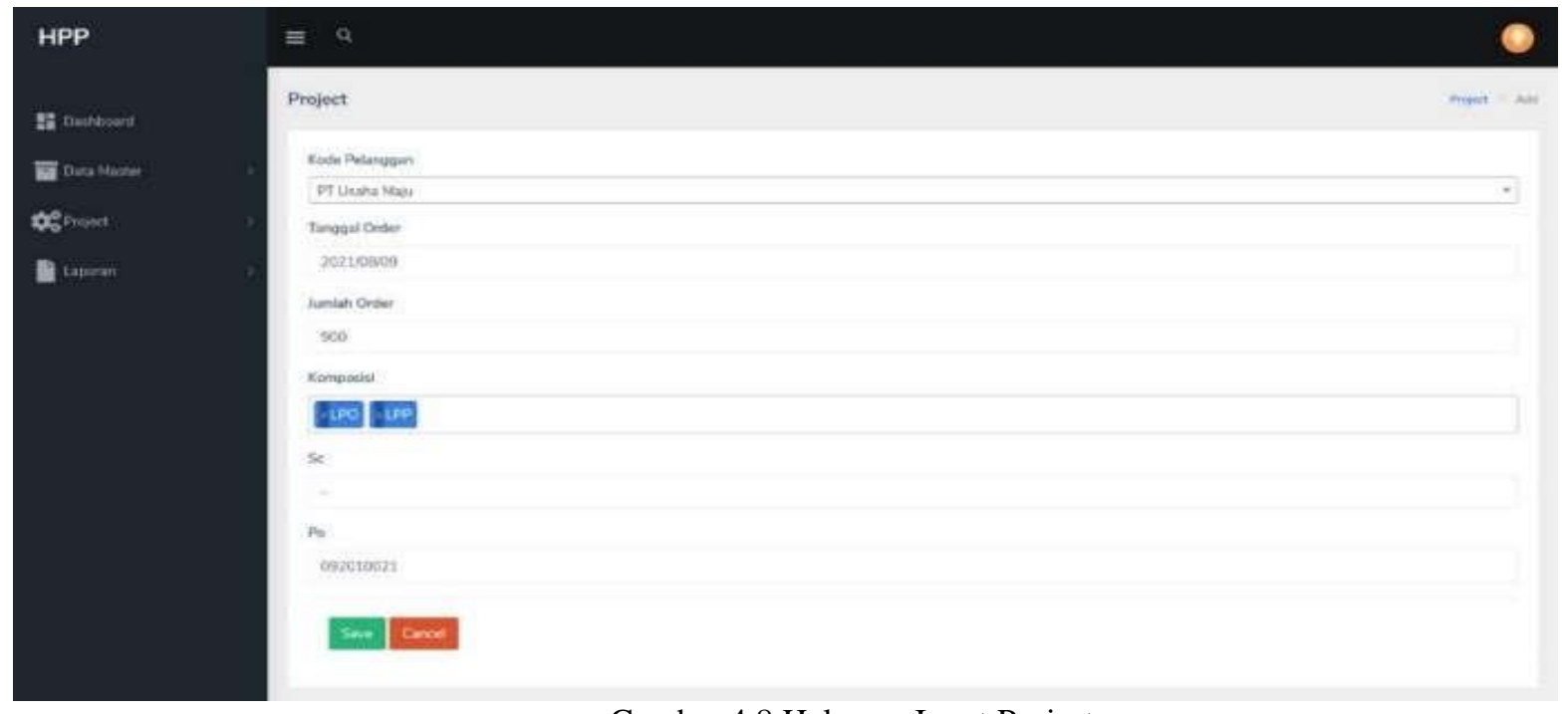

Gambar 4.8.Halaman Input Project

\section{Testing}

Testing ini di perlukan untuk menguji suatu program apakah program rancangan aplikasi ini dapat berjalan dengan baik tanpa suatu masalah atau tidak. Dalam pengujian ini penulis menggunakan metode blackbox testing untuk menguji tampilan luar.

\section{KESIMPULAN}

1. Sebelumnya perhitungan estimasi harga pokok penjualan dan produksi ini menggunakan aplikasi Microsoft excell.Dalam melakukan perhitungan harga pokok sering terjadi selisih karena ada ketidaksesuaian dalam menginput rumus pada microsoft excell. Dan penyimpanan juga tidak praktis karena memakai media flashdisk yang rentan rusak ataupun hilang.
2. Dengan menggunakan program perancangan aplikasi harga pokok penjualan dan produksi berbasis web ini maka di harapkan dapat memudahkan pengolahan data, memudahkan dalam pencarian data dan penyimpanan data menjadi lebih efektif dan efisien.

3. Dengan adanya aplikasi ini di harapkan dapat lebih menghemat kertas. Diharapkan setelah adanya aplikasi ini membuat laporan harga pokok menjadi lebih praktis saat di buat.

\section{UCAPAN TERIMA KASIH}

Terima kasih kepada PT Sinar Pelangi Kemasindo yang sudah memberikan kesempatan untuk melakukan penelitian. Kepada Dekan dan jajaran program studi Teknik Informatika Universitas Nusa Mandiri, untuk kepercayaan nya 
seminar ini. Bagian ini tidak harus ada dalam karya tulis Anda.

\section{DAFTAR ACUAN}

[1] Abdulloh, R. (2018). 7 in 1 Pemrograman Web

[2] Budiarto, R (2020) Rekayasa Perangkat Lunak GooglePlay.https://play.google.com/books/reader?id= xY7_DwAAQBAJ\&pg=GBS.PR2\&hl=id

[3] Ginantra, N. L. W. S. R., Wardani, N.,Aristami, G. A. A. M., Suryawan, W. D., \& Ardiana, D. putu Y. (2020). Basis Data: Teori dan Perancangan

[4] Kromann, F. M. (2018). Beginning PHP and MySQL: From Novice to Professional. http://e- resources.perpusnas.go.id 